\title{
PENGARUH BUDAYA ORGANISASI, GAYA KEPEMIMPINAN, DAN KEPUASAN KERJA TERHADAP KOMITMEN ORGANISASI
}

\section{Saut Purba}

\begin{abstract}
The objective of this research is to study the organizational culture, leadership style, and job satisfaction influence on the deans organizational commitment by private university in North Sumatera province. In this research, 90 samples were selected simple random sampling and data has been analysis by path analysis. The research findings are: (1)organizational culture has a direct effect on job satisfaction, (2) leadership style, has a direct effect on job satisfaction, (3) job satisfaction has a direct effect on organizational commitment, (4) organizational culture has a direct effect on organizational commitment, and (5) leadership style has a direct effect on organizational commitment. Efforts to improve organizational commitment can be done by creating conducive conditions in the workplace, employer-oriented leadership style to the task and the empowerment of subordinates, as well as increase job satisfaction by providing recognition, rewards and incentives, the results of this study can be considered for the next research.
\end{abstract}

Keywords: Organizational Commitment, Organizational Culture, Leadership Style, And Job Satisfaction.

\section{PENDAHULUAN}

Perguruan tinggi sebagai satuan pendidikan yang menyelenggarakan pendidikan tinggi mempunyai peran dan fungsi strategis dalam mewujudkan amanat Undang-Undang Nomor 20 Tahun 2003 tentang Sistem Pendidikan Nasional, yakni menghasilkan lulusan yang berahlak mulia, jujur, berkualitas, demokratis dan mampu mengahadapi tantangan dan persaingan antar bangsa. (Depdiknas, 2003:86).

Sehubungan dengan hal tersebut di atas, maka diperlukan adanya SDM yang handal dan dapat menghadapi tantangan, menciptakan serta mengisi peluang kerja, karena diindikasi salah satu penyebab terjadinya krisis ekonomi adalah rendahnya kualitas SDM. Kenyataan yang dihadapi, secara umum kualitas SDM Indonesia masih rendah, indikator rendahnya kualitas SDM di Indonesia ditandai dengan laporan data Human Development Indeks Report tahun 2010 (Menkokesra,2010:1) yang menempatkan Indonesia pada urutan ke 108 dari 169 negara di ASEAN. Indonesia di bawah Singapura (rangking 27, nilai 0,846), Brunei (rangking, 37, nilai 0,805, Malaysia (rangking 57, nilai 0,744), Thailand (rangking 92, nilai 0,654), Filipina (rangking 97, nilai 0,638), di atas, Vietnam (rangking 113, nilai 0,572), Laos PDR (rangking 122, nilai 0,497), Combodia (rangking, 122, jilai 0,494) Myanmar (rangking 132, nilai 0,451).

Indikator ini merupakan pengukuran kualitas hidup penduduk suatu negara pada aspek pendidikan, usia harapan hidup, tingkat melek huruf dan standar hidup. Rendahnya peringkat Indonesia dalam Human Development Index (HDI) dan mutu perguruan tinggi merupakan indikator rendahnya daya saing SDM Indonesia dibandingkan negara-negara lain di kawasan Asia-Pasifik. Bahkan untuk versi Times Higher Education Suplement (THES), hanya ada empat perguruan tinggi di Indonesia yang dapat masuk dalam jajaran 500 kampus ternama dunia, yakni Universitas Indonesia (UI) pada peringkat 250, Insititut Teknologi Bandung (ITB) dengan peringkat 258, Universitas Gajahmada (UGM) dengan peringkat 270, dan Universitas Diponegoro

\footnotetext{
- Staf Pengajar FT Universitas Negeri Medan
} 
(UNDIP) dengan peringkat 495. Ditambah pula untuk perguruan tinggi swasta hanya ada tiga universitas yang sudah mulai menyiapkan strategi dan kebijakan untuk menuju ke "World Class University" yakni Universitas Trisakti, Universitas Islam Indonesia Yogyakarta, dan Universitas Muhammadiyah Malang. (Yuhandi, 2006:41). Hal ini memperlihatkan bahwa mutu perguruan tinggi umumnya, khususnya perguruan tinggi swasta masih rendah.

Untuk menghasilkan mutu lulusan PTS yang setara dengan PTN sangat terasa sulit, namun salah satu upaya yang dapat dilakukan adalah mencermati komitmen dari setiap komponen/jajaran pimpinan PTS termasuk dekan sebagai pengelola kegiatan akademik di tingkat fakultas. Adapun tugas dan fungsi dekan dalam organisasi perguruan tinggi adalah: (1) Melaksanakan visi dan misi, (2) Memipin penyelenggaraan Tridharma Perguruan Tinggi, pendidikan, penelitian dan pengabdian pada masyarakat, (3) Meng-ajukan rencana anggaran pendapatan dan belanja fakultas kepada rektor untuk mendapat pengesahan setelah mendapat persetujuan senat fakultas, (4) Melaporkan dan mempertanggung jawabkan realisasi anggaran pendapatan belanja fakultas kepada senat fakultas, rektor, dan pengurus harian, (5) melaksanakan tugas manajerial di tingkat fakultas serta menjaga dan melaksanakan hubungan yang harmonis di lingkungan universitas, dan (6) Menyampaikan segala keterangan kepada rektor dan pengurus harian baik diminta atau tidak. (UISU,2006:23)

Memperhatikan deskripsi kerja di atas semestinya komitmen organisasi dekan merupakan hal yang mutlak dapat diperhatikan sebagai indikator penentu keberhasilan universitas. Namun kenyataannya pada universitas swasta di propinsi Sumatera Utara tidak demikian. Salah satu indikatornya adalah masa satu periode dekan, yaitu 4 (empat) tahun tidak dapat terselesaikan, bahkan sangat dimungkinkan terjadi pergantian dekan 2 sampai 3 kali selama masa satu periode. (Profil Kopertis Wilayah I,2008:223). Disamping itu, ada rektor setelah 6 (enam) bulan menjabat langsung mengundurkan diri. Terlepas dari intervensi pimpinan yayasan dan rektor, tingginya turn over dari para dekan ini merupakan suatu permasalahan dalam manajemen. Menurut Colquitt, Le Pine dan Wesson (2009:9), bahwa tingginya turn over pada suatu organisasi merupakan suatu indikasi rendahnya komitmen organisasi dari karyawan terhadap organisasi tersebut.

Banyak faktor yang diduga dapat mempengaruhi komitmen dekan di universitas swasta untuk meningkatkan mutu lulusannya. Faktor-faktor tersebut dapat diduga antara lain: reward yang tidak jelas, tingginya semangat kompetitif, kurangnya fasilitas, budaya kerja, iklim kerja, gaya kepemimpinan para rektor, pengetahuan yang dimiliki, kelancaran komunikasi di dalam organisasi, serta motivasi kerja dekan dan lain-lain.

Komitmen Organisasi. Komitmen organisasi dari seorang manajer sangat dibutuhkan untuk dapat mencapai tujuan organisasi. Komitmen organisasi merupakan faktor penentu atau pembeda adanya pekerja yang dalam posisi yang sama dan pekerjaan sama namun menunjukkan hasil kerja yang berbeda-beda. Colquitt.,LePine dan Wesson

(2009:67) mengungkapkan pengertian komitmen organisasi" as desire on the part an employee to remain a member of organization. Dengan kata lain, komitmen organisasi didefenisikan sebagai keinginan seorang karyawan untuk tetap menjadi anggota organisasi. Selanjutnya Mc.Sh'ane dan Mary Ann (2008:119) mengemukakan, komitmen 
organisasi merupakan pernyataan emosional karyawan untuk dan terlibat dalam sebuah organisasi tertentu. Hal ini memberi arti bahwa komitmen organisasi merupakan gambaran emosi karyawan yang diwujudkan dengan keterikatannya terhadap suatu organisasi tertentu. Luthans (2006: 249) menguatkan komitmen organisasi sebagai (1) Ke-inginan kuat untuk mempertahankan seorang anggota organisasi tertentu,(2) Sebuah kemauan yang kuat untuk mempertahankan nama organisasi, dan (3) Keyakinan dan penerimaan nilai-nilai dan tujuan organisasi. Dengan kata lain, hal tersebut merupakan sikap yang meref-leksikan kesetiaan karyawan terhadap organisasi dimana anggota dapat memusatkan perhatiannya pada keber-hasilan dan kemajuan organisasi secara berkelanjutan. Menurut George dan Jones (2005:75), yang dimaksud dengan komitmen organisasional merupakan kumpulan dari perasaan dan kepercayaan yang dimiliki oleh para karyawan terhadap organisasinya secara keseluruhan. George dan Jones (2005:75), menambahkan bahwa sikap-sikap pekerja, seperti kepuasan kerja dan komitmen organisasional, terdiri dari tiga komponen, yaitu : (1) perasaan, komponen kepedulian (affective), (2) kepercayaan, komponen kognitif atau pengertian, dan (3) pemikiran-pemikiran bagaimana untuk berperilaku atau komponen perilaku. Sementara itu, komitmen organisasi berhubungan erat dengan perasaan dan kepercayaan tentang organisasi secara keseluruhan.

Selanjutnya Robbins dan Judge (2009: 74), lebih menegaskan bahwa ada tiga dimensi komitmen organisasi, yaitu : (1) komitmen afektif atau keperdulian, (2) komitmen berkelanjutan, dan (3) komitmen normatif atau baku. Untuk lebih jelasnya dapat dirinci sebagai berikut.Pertama : komitmen afektif atau keperdulian (affective commitment). Komitmen ini merupakan keterkaitan emosi pada organisasi dan suatu kepercayaan terhadap nilai-nilainya. Seorang karyawan mungkin akan tetap peduli pada organisasi karena organisasi tersebut peduli dengan lingkungan seperti yang disukainya. Kedua: komitmen berkelanjutan (continuance commitment). Komitmen ini berkaitan dengan nilai ekonomis yang diterima jika tetap berada dalam organisasi bila dibandingkan dengan keluar dari organisasi. Misalnya, seorang karyawan mungkin berjanji kepada majikannya untuk tetap bekerja pada organisasi tersebut karena gaji besar dan akan merasa menyakiti keluarganya jika ia keluar. Ketiga : komitmen baku atau normatif (normative commitment). Komitmen ini berkaitan dengan kewajiban untuk tetap bertahan dalam organisasi karena alasan-alasan moral dan etika.

Berdasarkan uraian di atas, dapat disimpulkan bahwa yang dimaksud dengan komitmen organisasi adalah keberpihakan seseorang sebagai anggota organisasi terhadap organisasinya dengan berperan aktif dalam rangka mencapai tujuan, yang ditandai dengan keterikatan dengan organisasi, kepercayaan akan organisasi dan kesesuaian dirinya dengan tujuan-tujuan organisasi dengan indikator: (1) keterikatan dengan organisasi, (2) kepercayaan terhadap organisasi, dan (3) kesesuaian diri dengan organisasi.

Budaya Organisasi. Robbins dan Judge (2009: 585), memberi batasan tentang budaya organisasi sebagai berikut: organizational culture refers to a system of shared meaning held by members that distinguishes the organization from other organization, artinya budaya organisasi mengacu kesuatu sistem makna bersama yang dibentuk oleh anggotaanggotanya sekaligus pembeda organisasi. Dengan demikian setiap organisasi tidak harus memiliki budaya yang persis sama. Setiap organisasi memiliki budaya organisasi yang merupakan ciri khas, dan sekaligus merupakan pembeda dengan organisasi lain.. 
Berkaitan dengan hal ini, Luthans (2008:74), menambahkan," a pattern of basic assumption invented, discovered, or depeloved by a griven group as it learm to cope with as problems of external adaption and internal integration that has worked well enough to be considered valuable and, therefore, to be taught to new members as the correct way to percerceive, think, and feed in relation to those problems.Dari defenisi ini terlihat budaya organisasi sesungguhnya tumbuh karena diciptakan dan dikembangkan oleh individu-individu yang bekerja dalam suatu organisasi, dan diterima sebagai nilai-nilai yang harus dipertahankandan diturunkan kepada anggota baru.Nilai-nilai tersebut digunakan sebagai pedoman bagi setiap anggota selama mereka berada dalam lingkungan organisasi tersebut dan dianggap sebagai ciri khas yang membedakan sebuah organisasi dengan organisasi lainnya.

Selanjutnya Robbins (1994:480) menambahkan ada 10 (sepuluh) karak-teristik utama dari budaya organisasi, yaitu (1) Inisiatif individual, (2) Toleransi terhadap tindakan beresiko, (3) Arah, (4) Integrasi (5) Dukungan dari manajemen, (6) Kontrol, (7) Identitas, (8) Sistem Imbalan, (9) Toleransi terhadap konflik, dan (10) Pola-pola komunikasi.

Dari berbagai teori dan penelitian yang relevan di atas dapat disintesiskan budaya organisasi adalah seperangkat nilai utama, keyakinan, pemahaman, pola perilaku dan norma yang dimiliki bersama oleh semua anggota organisasi dengan indikator; inisiatif individu, toleransi terhadap tindakan beresiko, pengarahan, dukungan dari pimpinan, penghargaan, dan pola komunikasi, toleransi terhadap konflik, pengawasan, kerja sama, identitas.

Gaya Kepemimpinan Atasan. Dalam konteks organisasi membicarakan kepemimpinan merupakan sesuatu yang mutlak, karena berkaitan dengan perilaku antara pemimpin dengan orang yang dipimpinnya. Menurut Daft (2005:4), "leadership is influence relationship among leaders and followers who intend real changes and outcomes that reflect their shared purposes". (Kepemim-pinan adalah sebuah hubungan yang saling mempengaruhi di antara pemimpin dan pengikut (bawahan) yang menginginkan perubahan nyata yang mencerminkan tujuan bersamanya).Para ahli kepemimpinan telah meneliti dan mengembangkan gaya kepemimpinan yang berbeda-beda sesuai dengan evolusi teori kepemimpinan. Mempelajari subjek kepemimpinan dapat dilakukan dengan

cara berbeda-beda, tergantung pada konsep yang dipakai oleh peneliti mengenai kepemimpinan dan pilihan metodologi yang digunakan. Menurut (Daft, 2005:46-47), penelitian kepemimpinan umumnya terbagi pada garis penelitian yang jelas dan dapat diklasifikasikan menurut fokus utama seperti: (a) pendekatan Trait (sifat), (b) pendekatan perilaku, (c) pendekatan situasional, (d) pendekatan transaksional, (e) pendekatan transformasional, dan (f) pendekatan kepemimpinan karismatik.

Menyikapi teori-teori yang di kemukan di atas tentang gaya kepemimpinan, perguruan tinggi sebagai organisasi non profit sebaiknya tidak menerapkan gaya kepemimpinan yang otoriter karena tidak sesuai dengan suasana akademik yang ada diperguruan tinggi. Mengingat bentuk organisasi perguruan tinggi yang tidak berorientasi birokratik hirarkis yang kaku, karena gaya kepemimpinan yang demikian akan mematikan daya inovasi dan kreatifitas dikalangan staf pengajar. Selanjutnya dalam penelitian ini gaya kepemimpinan yang diteliti adalah gaya kepemimpinan yang yang berdasarkan temuan yang diperoleh oleh universitas Ohio, yaitu gaya kepemimpinan berdasarkan structure initiating dan consideration. Berkaitan dengan gaya 
kepemimpinan penelitian yang dilakukan Brown (2003:1), menemukan relation-oriented leadership memberikan variasi yang besar terhadap komitmen afektif dari 361 karyawan Charlottesville Virginia City.

Berdasarkan uraian beberapa konsep di atas selanjutnya dapat disintesiskan bahwa gaya kepemimpinan atasan adalah penilaian terhadap perilaku atasan dalam mempengaruhi bawahannya baik secara individu maupun kelompok untuk mencapai tujuan organisasi dengan indikator: prosedur kerja yang jelas, jalur komunikasi yang jelas, pengawasan yang ketat, sikap persahabatan, saling percaya, peng-hargaan, keramahan dan kekeluargaan.

Kepuasan Kerja. Setiap orang bekerja dalam suatu organisasi tentunya didasarkan adanya kebutuhan dalam dirinya. Kebutuhan tersebut merupakan gambaran harapanharapan yang menyangkut kebutuhan fisik dan non fisik. Terpenuhinya harapanharapan tersebut akan memberikan kepuasan, namun jika tidak terpenuhi maka akan memberi rasa tidak puas. Berkaitan dengan kondisi psikologis Kreitner dan Kinichi (2003:309), mengemukakan, kepuasaan kerja merupakan kesan atau tanggapan emosional terhadap sesuatu pekerjaan..Robbins(1998:84), mengungkapkan faktor-faktor yang mempengaruhi kepuasan kerja : The more important factors conducive to job satisfaction include mentally challenging work, equitable rewards, supportive working conditions, and supportive colleagues". Berdasarkan uraian di atas dapat diketahui bahwa kepuasan kerja lebih banyak dipengaruhi faktor kondusif yang berkaitan dengan mentalitas terhadap pekerjaan yang menantang, hadiah yang layak, kondisi lingkungan kerja, dan sikap dukungan dari rekan kerja.

Menurut Luthans (2006:126), terdapat 3 (tiga) dimensi penting dari kepuasan kerja, yaitu: (1) kepuasan kerja merupakan respons emosional dari situasi kerja yang tidak terlihat namun disimpulkan, (2) kepuasan kerja sering ditetapkan sebagai seberapa baik hasil yang diperoleh sama atau melebihi yang diharapkan, dan (3) kepuasan kerja menyajikan beberapa sikap yang saling berhubungan. Selanjutnya Judge dan Watanabe dalam Sopiah (2008;171), menambahkan sejumlah faktor yang berpengaruh terhadap kepuasan kerja, yaitu: kesempatan untuk promosi, faktor intrinsik, (3) kondisi kerja, (4) pendidikan, (5) usaha pribadi, (6) sistem gaji, (7) jam kerja, (8) hakikat pekerjaan, dan (9) kesempatan untuk maju dan berkembang.

Terdapat berbagai dimensi yang sudah diteliti dan diukur oleh Job Descriptive Index (JDI) yang berkaitan dengan kepuasan kerja di USA, dengan lima dimensi dan digunakan sebagai karakteristik yang banyak manfaatnya, yaitu: (a) Pekerjaan itu sendiri,

dengan adanya pertang-gungjawaban, kepentingan, bantuan sosial. (b) kualitas supervisi, dengan adanya bantuan teknis, bantuan sosial, $\quad$ (c) hubungan di antara pekerja, dengan adanya harmonisasi, penghormatan, (d) peluang untuk promosi, dengan adanya perubahan dan perkembangan di masa depan, (e) pembayaran, dengan adanya perolehan penghasilan dan perolehan lainnya sebagai tambahan"(2006:1).

Berdasarkan konsep dan teori tentang kepuasan kerja sebagaimana uraian di atas, dapat disintesiskan, kepuasan kerja adalah respon emosional mengenai perasaan suka atau positip terhadap aspek-aspek pekerjaan yang memberikan arti penting bagi pemenuhan kebutuhan psikologis dan fisik serta refleksi karyawan dalam memaknai pekerjaannya dengan indikator; (1) respon terhadap isi pekerjaan, (2) respon terhadap suasana kerja, dan (3) respon terhadap sistem ganjaran. 


\section{METODE}

Penelitian ini bertujuan untuk menguji pengaruh langsung: (1) budaya organisasi terhadap kepuasan kerja, (2) gaya kepemimpinan atasan terhadap kepuasan kerja, (3) kepuasan kerja terhaap komitmen organisasi, (4) budaya organisasi terhadap komitmen organisasi, dan (5) gaya kepemimpinan atasan terhadap komitmen organisasi. Penelitian ini dilaksanakan di universitas swasta provinsi Sumatera Utara selama 5 (lima) bulan yaitu mulai bulan Oktober 2009 sampai dengan Maret 2010. Dalam penelitian ini digunakan metode survey dengan pendekatan kausal.Untuk analisis data digunakan analisis jalur (path analysis). Populasi dalam penelitian ini adalah semua dekan universitas swasta di provinsi Sumatera Utara. Dari target populasi tersebut populasi terjangkau berjumlah 130 orang dan sampel sebanyak 90 orang. Selanjutnya teknik pengambilan sampel digunakan dengan teknik acak sederhana (simple random sampling).

\section{PEMBAHASAN}

\section{Pengaruh langsung positif Budaya Organisasi Terhadap Kepuasan Kerja}

Hipotesis 1 yang berbunyi, budaya organisasi berpengaruh langsung positif terhadap kepuasan kerja, ternyata signifikan dan ini diuji secara statistik. Hasil penelitian ini mendukung pendapat yang dikemukakan Wheelen \& Hunger yang yang dikutip Sopiah, mengemukakan bahwa budaya perusaha-an berperan penting dalam membantu stabilisasi perusahaan sebagai suatu sistem sosial, dan menjadikan pedoman perilaku sebagai hasil dari norma-norma terciptanya suatu organisasi yang efektif. Hasil penelitian ini juga mendukung hasil penelitian yang dikemukakan oleh Kreitner dan Kinicki, yang mengemukakan budaya konstruktif berhubungan secara positip dengan kepuasan kerja, dan keinginan untuk tidak keluar dari perusahaan dan inovasi. Hal ini menunjukkan bahwa para karyawan tampaknya lebih menyukai organisasi yang mendorong orang untuk berinteraksi dan bekerja dengan orang lain melalui cara membantu mereka memuas-kan kebutuhan untuk tumbuh dan berkembang. Akhir hasil penelitian menunjukkan bahwa kesesuaian antara nilai-nilai individu dengan nilainilai organisasi berpengaruh dengan komitmen organisasi, kepuasan kerja, intensitas untuk keluar dan pergantian karyawan.Selanjutnya temuan Tepeci dalam Sopiah mengungkapkan bahwa budaya organisasi berpengaruh terhadap tingkat kepuasan kerja.

Hasil penelitian ini memberi masukan bahwa budaya organisasi yang baik di perguruan tinggi swasta harus menganut prinsip good governance yang menuntut adanya

transparansi, akuntabilitas, pertanggungjawaban dan kejelasan. Melalui penciptaan good governance di universitas swasta, dekan akan dapat membentuk sendiri norma dan standar yang mereka miliki, selanjutnya akan berdampak kepada penghargaan dan pengakuan dari yayasan atau rektor atas prestasi mereka. Penerapan budaya organisasi yang menuntut adanya transparansi, akuntabilitas, pertanggung-jawaban dan kejelasan, yang akan dicirikan dengan adanya kegiatan universitas yang kontinuitas, misalnya adanya laporan tahunan yang lengkap dari segi keuangan dan tata kelola serta dipublikasikan secara lengkap. Adanya pembagian tugas, tanggung jawab, dan wewenang yang jelas. Nilai-nilai ini tentunya akan menyebabkan dekan di universitas swasta merasa memiliki dan dihargai, dampaknya adalah tercapainya misi dan tujuan universitas. 
Dengan demikian temuan ini semakin mempertegas hasil penelitian sebelumnnya yang membuktikan bahwa budaya organisasi merupakan faktor yang berpengaruh secara signifikan terhadap kepuasan kerja.

\section{Pengaruh langsung positif Gaya Kepemimpinan Atasan terhadap Kepuasan Kerja.}

Hipotesis 2 yang berbunyi, gaya kepemimpinan atasan berpengaruh langsung positif terhadap kepuasan kerja, ternyata signifikan dan ini diuji secara statistik. Hasil penelitian ini sesuai dengan hasil temuan Hellriegel, Slocum dan Woodman yang mengemukakan: The most positive effects of leader initiating structure on productivity and job satisfaction occurs when the task satisfies employees. Selanjutnya riset universitas Ohio dan Michigan yang menemukan bahwa kelompok kerja yang paling produktif cenderung mempunyai pemimpin yang berorientasi karyawan dari pada berorientasi produksi. Hasil penelitian ini mendukung temuan Colquitt, Le Pene and Wesson dalam "Integretive Model of Organization Behavior". Selanjutnya Cerit dalam penelitiannya terhadap 595 orang guru-guru sekolah dasar menemukan terdapat hubungan yang signifikan dan berarti antara perilaku kepemimpinan kepala sekolah dengan kepuasan kerja guru $(\mathrm{r}=0,589)$. Studi ini mendukung hasil penelitian Hebert (2003),Stockard and Lehman (2004), dan penelitian Miears (2004), dimana penelitian ini menggunakan 2(dua) dimensi kepuasan kerja yaitu intrinsic satisfaction dan extrinsic satisfaction.

Dengan demikian temuan ini semakin mempertegas hasil penelitian sebelumnya yang membuktikan bahwa gaya kepemimpinan atasan merupakan faktor yang berpengaruh secara signifikan terhadap kepuasan kerja.

\section{Pengaruh langsung positif Kepuasan Kerja terhadap Komitmen Organisasi}

Hipotesis 3 yang berbunyi, kepuasan kerja berpengaruh langsung positif terhadap komitmen organisasi, ternyata signifikan dan ini diuji secara statistik. Hasil penelitian ini mendukung temuan Colquitt Le Pene and Wesson, yang mengemukakan, job satisfaction has a strong positive effect of oganization commitment. Selanjutnya hasil penelitian ini juga sesuai dengan penelitian yang dikemukakan oleh penelitian Mubasysy et al, yang menemukan terdapat hubungan yang bermakna antara kepuasan kerja dengan komitmen organisasi. Kaitan antara kepuasan kerja dengan komitmen organisasi dapat didasarkan

suatu meta analisis dari 68 penelitian yang melibatkan 35.282 orang individu mengungkapkan hubungan yang signifikan dan kuat antara kepuasan kerja dengankomitmen organisasi. Melalui hasil penelitian ini para manajer disarankan untuk meningkatkan kepuasan kerja dengan tujuan untuk mendapatkan tingkat komitmen yang lebih tinggi.

Komitmen organisasi merupakan gambaran tingkat kesetiaan, keberpihakan seorang karyawan terhadap organisasinya. Menurut model teori yang dikemukakan oleh Robbins, bahwa tidak puas dan puas akan ditandai dengan empat respon, yaitu (1) keluar dari organisasi, (2) aspirasi, (3) kesetiaan, dan (4) pengabaian. Dari keempat respon kepuasan dan ketidak-puasan ini respon aspirasi dan kesetiaan dari karyawan memungkinkan karyawan untuk selalu dalam organisasi, dimana mereka menginginkan adanya serikat pekerja dan perputaran karyawan. Model ini memberi petunjuk untuk yayasan dan rektor agar dapat merespons ide-ide yang konstruktif dari dekan sehingga tingkat kepercayaan, keterlibatan dan kesetiaan mereka dalam meningkatkan mutu lulusan univeritas akan semakin meningkat. Selanjutnya hasil 
empirik penelitian ini mendukung penelitian yang dilakukan selama kurang lebih lima puluh tahun yang lalu di Amerika Serikat, Inggris dan Jepang, dimana instrumen yang digunakan adalah Job Description Indeks (JDI), yang menemukan terdapat hubungan yang sangat positif antara kepuasan kerja dengan komitmen organisasi. Hasil penelitian ini memberikan petunjuk, bahwa faktor-faktor ekstrinsik (gaji, kondisi kerja, hubungan dengan atasan, supervisi, hubungan dengan sejawat, hubungan dengan bawahan) tetap untuk diberikan, namun faktor-faktor motivator (prestasi, pengakuan, kerja itu sendiri, tanggung jawab, dan kemajuan), merupakan faktor penentu untuk untuk meningkatkan komitmen terhadap organisasi dan kinerja karyawan.

Dengan demikian temuan ini semakin mempertegas hasil penelitian sebelumnya yang membuktikan bahwa kepuasan kerja merupakan faktor yang berpengaruh secara signifikan terhadap komitmen organisasi.

\section{Pengaruh langsung positif Budaya Organisasi terhadap Komitmen Organisasi.}

Hipotesis 4 yang berbunyi, budaya organisasi berpengaruh langsung positif terhadap komitmen organisasi, ternyata signifikan dan ini diuji secara statistik. Hasil penelitian ini sesuai dengan pernyataan Robbins yang mengemukakan budaya organisasi menuntut agar para anggotanya merasa bangga meng-identifikasikan dirinya dengan organisasi. Hal itu hanya akan timbul apabila semua anggota organisasi merasa memiliki organisasi tersebut. Selanjutnya ditam-bahkan budaya organisasi sebagai konsekuensi logis dari rasa memiliki organisasi, para anggota organisasi akan bersedia membuat komitmen termasuk memberikan pengorbanan sedemikian rupa, sehingga mereka akan ikhlas bekerja demi keberhasilan organisasi. Budaya organisasi akan menumbuhkan identitas dalam diri setiap anggotanya dan keterikatan terhadap organisasi, karena kesamaan nilai yang tertanam akan memudahkan setiap anggota organisasi untuk memahami dan menghayati setiap peristiwa maupun kegiatan yang dilakukan oleh organisasi. Pemahaman mengenai budaya organisasi selain untuk memudah-kan pemecahan masalah internal seperti imbalan, kinerja atau pengembangan karir, juga akan membantu organisasi menghadapi masalah-masalah yang berkaitan dengan penyesuaian

terhadap lingkungan eksternalnya sehingga diharapkan organisasi dapat terus bertahan dalam segala kondisi, sehingga budaya organisasi perlu dipelihara. Untuk dapat melakukan pemeliharaan budaya organisasi yang kuat, sesuai dan adaftif di universitas swasta dengan baik, maka diperlukan langkah langkah, yaitu : Pemimpin lembaga (yayasan ataupun rektor) harus senantiasa memberikan dorongan kepada dekan untuk meng-implementasikan budaya organisasi dalam setiap pertemuan atau melalui sharing (share thing, share saying, share doing, dan share feeling), disamping itu yayasan atau rektor harus memberikan keteladanan terutama dalam lingkungan yang bersifat paternalistik yang menempatkan mereka sebagai central figure. Yayasan dan rektor senantiasa memberikan penjelasan dan menekankan bahwa budaya organisasi yang dimiliki universitas akan semakin kaya dan kuat karena dibangun melalui sinergisme diantara subculture yang ada di lembaga.

Pendapat ini sangat sesuai dengan hasil penemuan secara empirik, dimana dari indikator budaya organisasi, yaitu dukungan dari manajemen memberikan sumbangan yang paling besar diantara indikator lainnya, yaitu sebesar 33,524\% terhadap komitmen organisasi. Hal ini memberi arti bahwa setiap ide-ide kreatif, inovatif maupun kebijakan yang dilakukan dekan selama ini tidak sepenuhnya mendapat dukungan dari yayasan maupun rektor.Hal ini tentunya dapat mengindikasi mengapa sering seorang dekan 
tidak menyelesaikan jabatannya selama periode.Hasil penelitian ini mendukung pendapat Kreitner dan Kinicki, yang mengemukakan perlunya nilai-nilai pendukung (espaused values), yaitu nilai-nilai yang dinyatakan secara eksplisit oleh organisasi, dan nilai -nilai yang diperankan (enacted values), yaitu nilai dan norma yang sebenarnya ditunjukkan ke dalam perilaku karyawan. Kedua nilai tersebut akan merupakan indikator integritas seorang karyawan menjalankan komitmennya.

Dengan demikian temuan ini semakin mempertegas hasil penelitian sebelumnya yang membuktikan bahwa budaya organisasi merupakan faktor yang berpengaruh secara signifikan terhadap komitmen organisasi.

\section{Pengaruh langsung positif Gaya Kepemimpinan Atasan terhadap Komitmen Organisasi.}

Hipotesis 5 yang berbunyi, gaya kepemimpinan atasan berpengaruh langsung positif terhadap komitmen organisasi, ternyata signifikan dan ini diuji secara statistic. Hasil penelitian ini mendukung teori Fiedler yang mengemukakan bahwa kunci kesuksesan seseorang pemimpin terletak pada gaya kepemimpinannya. Selanjutnya berkaitan dengan gaya kepemimpinan penelitian yang dilakukan Brown, menemukan relation-oriented leadership memberikan variasi yang besar terhadap komitmen afektif dari 361 karyawan Charlottesville Virginia City.

Berdasarkan hasil penelitian ini dapat dinyatakan untuk organisasi nir laba seperti universitas swasta sebaiknya dalam melaksanakan kepemimpinannya dapat menggunakan gaya kepemimpinan yang dikemukakan oleh Reddin yang dikutip oleh Thoha, yaitu gaya kepemimpinan yang efektif, yaitu sebagai (1) pelaksana (executive), (2) pecinta pengembang (developer), (3) otokratis yang baik hati (benevolent autocraf), dan (4) birokrat (bureaucrat). Gaya kepemimpinan ini diasumsikan efektif karena situasisituasi tertentu menuntut satu gaya kepemim-pinan tertentu, sedangkan situasi lainnya menuntut gaya yang lain pula.

Dengan demikian temuan ini semakin mempertegas hasil penelitian sebelumnya yang membuktikan bahwa gaya kepemim-pinan atasan merupakan faktor yang berpengaruh secara signifikan terhadap komitmen organisasi.

\section{PENUTUP}

Kesimpulan. Berdasarkan analisis terhadap hasil penelitian dapat disampaikan beberapa temuan penelitian sebagai berikut:

1. Budaya Organisasi berpengaruh langsung positif terhadap Komitmen Organisasi. Artinya Budaya Organisasi yang kuat, tepat, dan sesuai mengakibatkan meningkatnya Kepuasan Kerja dekan universitas swasta di propinsi Sumatera Utara.

2. Gaya Kepemimpinan Atasan berpengaruh langsung positif terhadap Kepuasan Kerja. Artinya Gaya Kepemimpinan Atasan yang efektif mengakibatkan meningkatnya Kepuasan Kerja dekan universitas swasta di propinsi Sumatera Utara.

3. Kepuasan Kerja berpengaruh langsung positif terhadap Komitmen Organisasi. Artinya Kepuasan Kerja yang tinggi mengakibatkan meningkatnya Komitmen Organisasi dekan universitas swasta di propinsi Sumatera Utara.

4. Budaya Organisasi berpengaruh langsung positif terhadap Komitmen Organisasi.Artinya Budaya Organisasi yang kuat, tepat dan sesuai mengakibatkan meningkatnya Komitmen Organisasi dekan universitas swasta di propinsi Sumatera Utara.

5. Gaya Kepemimpinan Atasan berpengaruh langsung positif terhadap Komitmen Organisasi. Artinya Gaya Kepemimpinan Atasan yang efektif mengakibatkan 
meningkatnya Komitmen Organisasi dekan universitas swasta di propinsi Sumatera Utara.

Implikasi. Hasil penelitian mengenai Komitmen Organisasi dekan universitas swasta di propinsi Sumatera Utara memberikan implikasi sebagai berikut:

1. Peningkatan Budaya Organisasi akan berdampak pada peningkatan Kepuasan Kerja. Dengan demikian jika meningkatkan kepuasan kerja dekan di universitas swasta di propinsi Sumatera Utara, maka dibutuhkan peningkatan budaya organisasi yang dilakukan melalui peningkatan dan penciptaan dan pemeliharaan nilai-nilai, aturan dan norma-norma universitas yang jelas, melalui komunikasi diantara staf dosen dengan staf administrasi yang efektif, dan penciptaan identitas universitas yang jelas.

2. Peningkatan Gaya Kepemimpinan Atasan akan berdampak pada peningkatan Kepuasan Kerja. Dengan demikian jika meningkatkan kepuasan kerja dekan universitas swasta di propinsi Sumatera Utara, maka dibutuhkan gaya kepemimpinan yang efektif yang dapat dilakukan melalui prosedur kerja yang jelas, pola organisasi yang teratur, jalur komunikasi yang jelas, pengawasan yang ketat, sikap persahabatan atasan, menciptakan rasa saling percaya, memberikan penghargaan, dan mengupayakan keramahan dan kekeluargaan.

3. Peningkatan Kepuasan Kerja akan berdampak pada peningkatan Komitmen Organisasi Dekan. Dengan demikian jika meningkatkan Komitmen Organisasi dekan universitas

swasta propinsi Sumatera Utara, maka dibutuhkan terpenuhinya kepuasan kerja, yang dapat dilakukan melalui penciptaan isi pekerjaan yang jelas dan konsisten, dukungan atasan dan dukungan rekan kerja yang baik, suasana kerja yang menarik, dan pemberian sistem ganjaran yang jelas.

4. Peningkatan Budaya Organisasi akan berdampak pada peningkatan Komitmen Organisasi. Dengan demikian jika meningkatkan Komitmen Organisasi maka dibutuhkan peningkatan kualitas budaya organisasi yang dapat dilakukan melalui penempatan orang dalam pekerjaan sesuai dengan kemampuan dan bidangnya" the right man on the right place and the right time, dan penghayatan akan nilai-nilai kerja sebagai semangat dan kebanggaan terhadap organisasi serta dukungan dari manajemen.

5. Peningkatan Gaya Kepemimpinan Atasan akan berdampak pada peningkatan Komitmen Organisasi. Dengan demikian, jika memperbaiki Komitmen Organisasi dekan universitas swasta di propinsi Sumatera Utara, maka dibutuhkan pola kepemimpinan atasan yang efektif, yang dapat dilakukan melalui pemberian kesempatan kepada dekan untuk merencanakan, melaksanakan dan mengevaluasi kegiatan dengan tetap di bawah pengawasan rektor. Membicarakan kebijakankebijakan yang berkaitan dengan peningkatan universitas, mengambil konsensus, dan menciptakan keharmonisan.

Saran. Berdasarkan kesimpulan dan implikasi penelitian di atas, dapat dikemukakan beberapa saran bagi peningkatan Komitmen Organisasi dekan universitas swasta di propinsi Sumatera Utara, sebagai berikut:

1. Hendaknya yayasan universitas di propinsi Sumatera Utara mampu dan tetap mempertahankan nilai-nilai dominan, norma, aturan perilaku, pemahaman tentang peraturan-peraturan yang berlaku di universitas dan menghindarkan ketidakpastian tujuan universitas agar masyarakat yakin, bahwa keberadaan universitas adalah untuk menciptakan sarjana-sarjana yang berkualitas dan mandiri. Untuk dapat 
mempertahankan nilai-nilai, peraturan dan norma-norma yang mendukung tercapainya tujuan fakultas dapat dilakukan dengan mengadakan pertemuan sekali dalam satu semester antara pimpinan universitas dengan para dekan, dosen dan staf administrasi.Pengukuran prestasi dan pemberian imbalan yang sesuai, pengakuan dan promosi bagi dekan yang berprestasi. Disamping itu mengupayakan perberdayaan staf pengajar yang telah memiliki jenjang pendidikan yang lebih tinggi, mendorong dekan untuk aktif dalam penelitian dan pengabdian masyarakat, menambah fasiltas praktek/laboratorium, meningkatkan kerjasama dengan stakehorder, memperhatikan kondisi psiklogis bawahan, disamping memberikan motivasi kepada dekan untuk selalu aktif dalam hibah-hibah kompetetif, memperhatikan fasilitas, dan kesejahteraan bawahan.

2. Selanjutnya karena peluang lulusan universitas untuk menjadi PNS sangat terbatas, dan sesuai dengan saran dari para dekan, perlu untuk menciptakan budaya kewirausahaan melalui dukungan yayasan dengan penyediaan workshop yang memadai, dan fasilitas yang mendukung perkuliahan, serta kesejahteraan dosen yang jelas.

3. Hendaknya dalam memimpin rektor tetap konsisten dan konsekuen untuk mengambil keputusan selalu berorientasi kepada kepentingan akademik dan pemberdayaan dekan bukan hanya berorientasi kepada komersialisasi. Hal ini dapat dilakukan melalui

mengadakan rapat sekali dalam seminggu, bukan karena hanya ada masalah, dan memberikan kesempatan dekan memberikan pendapat untuk meningkatkan kualitas lulusan yang sesuai dengan misi dan tujuan universitas.

4. Karena kepuasan kerja merupakan sikap dan respon terhadap isi pekerjaan, suasana kerja dan iklim kerja, maka yayasan hendaknya memperhatikan kesejahteraan dekan, melalui pemberian gaji yang tepat waktu, imbalan kerja yang sesuai dengan beban kerja, dan penghargaan tertentu terhadap prestasi dekan yang mampu meningkatkan kualitas fakultas di tingkat nasional.

5. Hendaknya Dirjen Dikti melalui Kopertis Wilayah I NAD-Aceh dapat lebih tegas dalam penentuan akreditasi dari program studi, karena peringkat akreditasi sering tidak sesuai dengan kondisi universitas yang sebenarnya.

6. Masyarakat dan Pemerintah daerah hendaknya turut mengawasi perkembangan universitas, agar universitas konsisten dan konsekuen melaksanakan visi dan misinya, dan mendukung keberadaan universitas untuk menciptakan budaya enterpreneursip dan bukan sebagai penghasil sarjana pencari kerja tetapi pencipta kerja.

7. Para peneliti bidang manajemen pendidikan hendaknya dapat melanjutkan penelitian ini dalam rangka meningkatkan komitmen organisasi dekan universitas swasta di propinsi Sumatera Utara, melalui penyertaan variabel-variabel lain dan dengan analisis yang lebih akurat lagi. 


\section{DAFTAR RUJUKAN}

Brown, B. Barbara. Employee's organizational commitment and their perception of supervision,s. Relation-oriented and task-oriented leadership behavior. Disertasi. Virginia University: Charlottesville. 25 March, 2003.

Coulquitt ,J, A.,Le Pine, J,A. and Wesson,M.J. Organizational Behavior. Improving Performance and Commitment in The Workplace. New York: Mc Graw-Hill International Edition, 2009.

Daft.L.R..The Leadership Eksperience. Ohio :South-Western.2005.

Jeniffers.G,M. and G.R. Jones, Understanding and Managing Organizational Behavior. Fourth Editorial Upper Saddle River, New Jersey: Pearson Education, Inc, 2005.

Kreitner, Robert and Kinichi,.Angelo, Perilaku Organisasi. Terjemahan Erly Suandy buku 2. Jakarta: Salemba Empat.2003

Luthans Fred. Organization Behavior.Eleventh Edition. New York: McGraw Hill International Edition. 2008.

Mc.Shane, L.Steven and Mary Ann, Von Glibav.Organizational Behavior. New York. Mc Graw Hill Companies, Inc, 2008.

Robbins, S. P and T, A, Judge.Organizational Behavior, New Jersey Person. International Education, 2009.

Sopiah, Perilaku Organisasi. Yogyakarta: Penerbit Andi, 2008. 